高分子論文集 (Kobunshi Ronbunshu), Vol. 42, No. 8, pp. 509-516 (Aug., 1985)

\title{
カーボンブラックへのポリエステルのアニオングラフト重合に及ぼす クラゥンエーテルの添加効果*
}

\author{
坪川 紀夫*1 ・ 山田 昭洋*1 ・曽根 康夫*1
}

(受付 1985 年 3 月 30 日・籍查終了 1985 年 5 月 9 日)

\begin{abstract}
要 旨 カーボンブラック (CB) 表面へ導入したカリウムカルボン酸塩 (COOK) 基で開始される エボキシドまたはアルキレンカルボナートと渨状酸無水物との開鱑共重合による CBへのポリエス テルのグラフト反応に及ほす，18-クラウン-6 (CE) の添加奻果について検討した.

CB-COOKによるエピクロルヒドリンと無水フタル酸との開環共重合速度は, CEの添加により, 末添加の系の約 10 倍となった。 また, CBへのポリェステルのグラフト事は CE を添加しない系 では 63\% 以上にならないのに対して，CE の存在下では短時間のらちに，128\% まで増大した。更 に, CB-COOK による $\beta$ にプロピオラクトンの開環グラフト重合に扔いても，同様の添加奻果が認め られた。，以上の結果から，CB-COOK を用いるアニオングラフト重合において，グラフト率の大き なものを得るためには，CEの添加が極めて奻果的であることがわかった。
\end{abstract}

\section{1 萿 言}

すでに著者らは, カーポンブラック (CB) 表面のカル ポキシル基を丁ルカリ金属水酸化物 $(\mathrm{MOH}: \mathrm{M}=\mathrm{Li}$, $\mathrm{Na}, \mathrm{K}, \mathrm{Rb}$, Cs) で処理して CB 表面へ導入したアル
カリ金属カルボン酸塩 (COOM) 基により， $\beta$-プロピオ ラクトン (PL) のアニオン開環重合1やエポキシドある いはフルキレンカルボナートと環状酸無水物とのフ二オ ン開環交互共重合が開始され，様々な構造を持つポリエ ステルが CB 表面へグラフトすることを報告した2),3).

n
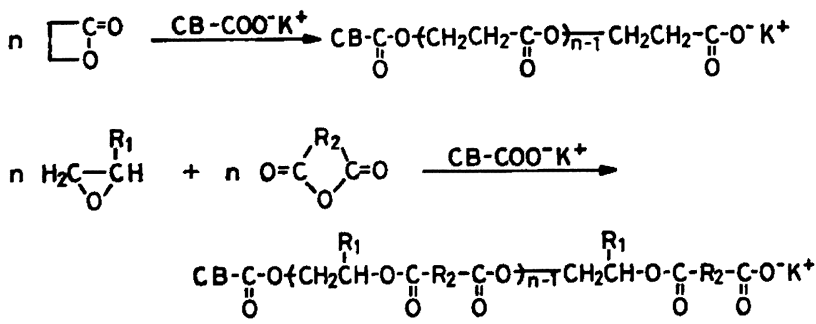

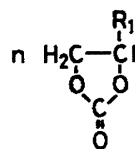
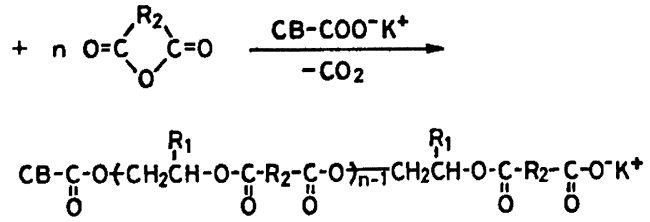

更に, CB 表面へのポリエステルのクララフト革に及任 才重合温度や用いる溶媒の誘奄率あるいは対カチオン $\left(\mathbf{M}^{+}\right)$の影筫を詳細に検討した4),5). その結果, 重合温

*本埌を「カーボンブラックへのボリェステルのグラ フト第 6 報」とする。

*1 新湯大学工学部応用化学科（函950-21 新淿市五十 島二の町 8050)
度が高いほど，また話電率の大きい溶媒の系ほど，重合 速度は大きくなるが，CB 表面から生長をはじめたボリ マー鎖の連銷移諪反応が起こりやすくなるため，クラフ ト率は逆に低下することを見いたした.

一方，フニオン重合系へ対カチオンの錯化剂として, クラウンエーテルやクリブタンドを添加すると，アニオ ンが活性化され重合速度が著しく增大し，分子量の大き 
なポリマーが生成することが知られている゙．たとえば， 䣫酸ナトリウムなどのアルカリ金属カルボン酸塩を触媒 に用いる PL のアニオン重合系ヘクラウンエーテルを添 加すると，重合速度はクラウンェーテルを加えない系の 100 倍以上になる場合がある7。

ところで, ポリマーグラフト CB の有機溶媒中への分 散安定性と CBへのポリマーのグラフト率とは密接に网 連しており，分散安定性を向上させるためには, タラフ ト率を高める必要がある．また，ポリマー中へ简単な操 作で CB を多量に，そして均一に配合し，しかす材料の 強度を低下させないようにするためには，やはり高グラ フト率のポリマークラフトCBを調製することが望まし い.

そこで，本研究では，高グラフト率のポリエステルク ラフト CB を得る目的で, CB 表面へ導入した COOK 基で開始されるエボキシド（またはアルキレンカルボナ 一ト）と㻴状酸無水物とのアニオン開環共重合，及び PL のアニオン開㻴重合に及ぼす 18-クラウン-6 (CE) の添加効果について検討した.

\section{2 实雅方法}

\subsection{CB と垉菜}

実験に用いた CB は，チャンネル系の Neospectra II (Columbian Carbon 社製; 比表面櫴 $906 \mathrm{~m}^{2} / \mathrm{g}^{8)}, \mathrm{pH}$ 39)，カルボキシル基 $0.40 \mathrm{meq} / \mathrm{g}$ ) である.

モノマーとして用いたエボキシド5)，環状酸無水物(), アルキレンカルボナート ${ }^{3)}$ ，及び $\mathrm{PL}^{1)}$ は前報に従って 精製した。また，エポキシドとして今回新たに用いたク リシジルフェニルェーテル (GPE) は, 東京化成工業 (株) 製の一級品を窒素ふん团気下で減圧蒸留した後，水 素化カルシウムで脱水し，重合直前に再蒸留した。

クラウンエーテルとしては 18-クラウン-6 (CE) を選 び，東京化成工菜(株) 製の特級品を室温で十分真空乾嬠 させてから使用した。

溶媒の $m$-キシレンは浱硫酸で洗浄し，金属ナトリウ ム上で僄流した後, 蒸留して使用した. ジクロロメタン は，希硫酸で洗浄した後，塩化カルシウム上で一夜脱水 し，2回蒸留を繰り返し精製した．の-ジクロロペンゼン は溜硫酸で洗浄した後, 塩化カルシウム上で一夜脱水 し， 2 回減圧蒸留を行ってから使用した.

\section{$2.2 \mathrm{CB}$ 表面への COOM 基の望入}

COOM 基を導入した CB の調製は, 表面のカルボキ シル基を対応するフルカリ金属水酸化物の水溶液で中和 処理することにより行った．実験方法の詳細は，前報で 述べだリ.

\subsection{I合方法}

重合は，十分乾燥した $0.30 \mathrm{~g}$ の CB-COOM を入れ た $100 \mathrm{~m} l$ のナス型フラスコに, 所定量の CE を溶解
した溶媒 $3.0 \mathrm{ml}$ 及びモノマーを加え，空案ふん囲気中， マグネチックスターラーでがさ混ぜながら行った，反応 後生成物を多再のメタノール中へ注き， CB を含さボリ マーを沈殿させた．沈股物は $40^{\circ} \mathrm{C}$ で佰量になるまで真 空䏠燥させた後科正し，次式から重合率を求めた。

$$
\text { 重合率 }(\%)=\frac{\text { 生成物 }(\mathrm{g}) \text {-用いた CB }(\mathrm{g})}{\text { 用いたモノマ-(g) }} \times 100
$$

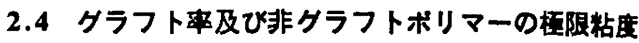

生成物をク口ロホルム中へ分散させて，10‘ rpm て透 心分離を行いCB を沈降させた。 ついで沈殿した CB を円简沪紙へ移し，クロロホルムを溶媒に用いてンック スレー抽出を行い, 非グラフトポリマーを完全に除去し た. CBへのボリェステルのクラフト华は，次式から 求めた。

$$
\text { グラフト率 }(\%)=\frac{\text { クラフフトしたポリマー }(\mathrm{g})}{\text { 用いた } \mathrm{CB}(\mathrm{g})} \times 100
$$

一方，遠心分離の上澄液から得られた非クラフトボリ マーの極限粘度はクロロホルムを溶媒に用いて, $30.0^{\circ} \mathrm{C}$ で測定した.

\section{3 結果と考察}

\section{1 閶环共重合速度に及はす CE の効果}

フニオン重合系において，その生長末端であるフニオ ソの求核性を增大させようとする試みがいろいろな角度 から検討されている，たとえは，Li， Na，K などのて ルカリ金属触某によるアニオン重合において，クラウン エーテルやクリブタンドを添加すると，スチレンやイン プレンなどを瞬間的に，しかむ定量的に重合することが でさる゚、10). 更に，酢酸ナトリウムなどのアルカリ金属 カルボン酸塩を用いる PL のアニオン用環重合系へク ラウンエーテルマやクリブタンドはをを加えると，非常に 活性なアニオンが生成し, 重合速度が著しく增大すると ともに，高分子量のボリマーが生成することが報告され ている.

先にす述べたよらに，著者らは CB へ塑した COOM 基によりェボキシドと環状酸無水物とのアニオ ン共重合が開始され， CB 表面へポリェステルがグラフ トすることを見いだした2)。そこで，まず CB-COOK を触媒に用いるエピクロルヒドリン $(\mathrm{ECH})$ と無水フタ ル酸 (PAn) とのフ二オン開環重合に及ぼす CE の添 加効果について検討した.

実験の結果を Fig. 1 に示したが,これから，CEの添 加量が多くなるに従って, 重合速度が著しく增大するこ とが明らかである。また，CE を加えない系中添加量の 少ない系では，重合時間を延長しても，ある重合帝以上 反応が進行しないのに対して, CE を $0.03 \mathrm{~g}$ 以上添加 した系では，重合が注定最的（重合事 $100 \%$ まて)下 進行することがわかる. 


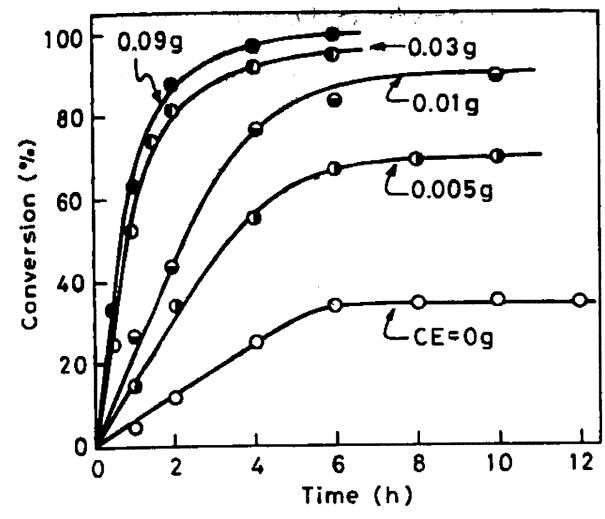

Fig. 1. Effect of 18-crown-6 on the copolymerization of epichlorohydrine (ECH) with phthalic anhydride (PAn) initiated by COOK groups on carbon black (Neospectra II-COOK, $0.30 \mathrm{~g} ; \mathrm{ECH}$ $=\mathrm{PAn}=0.01 \mathrm{~mol} ; \mathrm{m}$-xylene, $3.0 \mathrm{ml} ;$ temp., $120^{\circ} \mathrm{C}$ ).

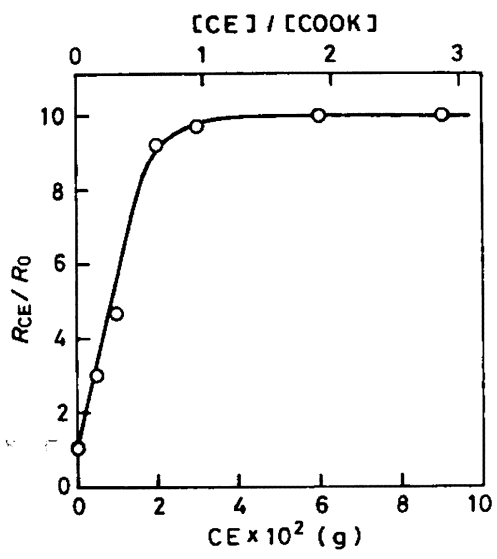

Fig. 2. Relationship between the amount of 18crown-6 (CE) and the rate of the copolymerization of ECH with PAn (Reaction conditions are given in Fig. 1): $\boldsymbol{R}_{0}$, the rate of copolymerization in the absence of $\mathrm{CE} ; \boldsymbol{R}_{\mathrm{CE}}$, the rate of copolymerization in the presence of $C E$.

これは，CE の添加による crown ether separate ion pair の生成に伴い，（1）アニオン重合威始種であ るCB 表面のカルボキシラートフニオンの見挂けの謷度 が增大すること，(2) フニオンの活性化により，生長速 度が增大することによるものと推察できる.

更に, CE の添加による初期重合速度の加速奻果を明 らかにするために, $\mathrm{CE}$ の添加量と $R_{\mathrm{CE}} / R_{0}\left(R_{0}, \mathrm{CE}\right.$ を 添加しない系の重合速度, $\boldsymbol{R}_{\mathrm{CE}}, \mathrm{CE}$ 存在下の重合速度) との咸係を Fig. 2 に示した．Fig. 2 の上軸には，用い

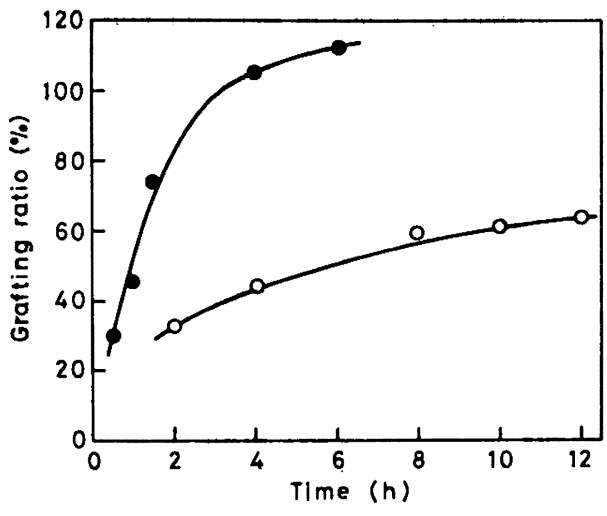

Fig. 3. Effect of 18-crown-6 on the grafting of polyester from ECH and PAn onto carbon black (Neospectra II-COOK, $0.30 \mathrm{~g} ; \mathrm{ECH}=\mathrm{PAn}=0.01$ mol; $m$-xylene, $3.0 \mathrm{ml}$; CE, $0.03 \mathrm{~g}$; temp. $120^{\circ} \mathrm{C}$ ): $(0)$, in the absence of $\mathrm{CE} ;(0)$, in the presence of $C E$.

た Neospectra II 表面の COOK 基量に対する添加し た CE のモル比が示してある.

Fig. 2 より, 重合速度の加速効果 $\left(R_{\mathrm{CE}} / \boldsymbol{R}_{0}\right)$ は $\mathrm{CE}$ の添加量とともに増大し, 添加量か; $0.03 \mathrm{~g}$ 付近 (CB 表 面の COOK 基とほぼ当量) で 10 倍に達し, その後一 定となることがわかる。そこで，以後の実験では， Neospectra II $0.30 \mathrm{~g}$ に対して，添加する CE 量を $0.03 \mathrm{~g}$ とした.

\section{2 ポリエステルのクララフ虫及ひ非クラフトポリ マーの分子吾に及ばす CE の効果}

Fig. 3 には，CB-COOK を触媒に用いる $\mathrm{ECH}$ と PAn との開環共重合系で得られる CBへのポリェステ ルのグラフト率に及ぽす CE の効果を調べた結果を示 した. 先にも述べた (Fig. 1) ように, CE の存在しな い系では重合率が $40 \%$ 以上にならないのに対応して， グラフト率も63\% を越えるすのが得られない。これに 対して，CE の存在下では，6時間後にクラフト率は 111.7\% にまで達し, 効率良く CB 表面へボリェステル をクラフトできることを Fig. 3 は示している.

更に,このよらな重合系で生成する非グラフトポリマ 一の極限粘度 $[\eta]$ (クロロホルム溶液， $30.0^{\circ} \mathrm{C}$ ) に及ほ す CE の効果を調へた結果を Fig. 4 に示した. CE の 存在しない系では [ク] が 0.065 以上のるのが得られな いのに対して，CE の存在下では，[ク] は重合の進行と ともに大きくなり，CE を添加しない系に比べて分子量 の大きなポリマーが生成することが明らかになった。

ところで，すでに報告したように，CB-COOK によ るエポキシドと酸無水物とのアニオン開環共重合の系で は, 用いる溶媒の誘電率が大きい系ほど重合速度は大き 
Table 1. Effect of 18-crown-6 on the copolymerization of epoxide with cyclic acid anhydride ${ }^{\text {? }}$

\begin{tabular}{|c|c|c|c|c|c|c|}
\hline Epoxide $^{b)}$ & Anhydride $^{\text {) }}$ & $\begin{array}{c}\text { Temp. } \\
\left({ }^{\circ} \mathrm{C}\right)\end{array}$ & $\underset{\text { (h) }}{\text { Time }}$ & $\begin{array}{c}\mathrm{CE}^{\mathrm{d})} \\
(\mathrm{g})\end{array}$ & $\begin{array}{c}\text { Conversion } \\
(\%)\end{array}$ & $\begin{array}{l}\text { Grafting } \\
\text { ratio (\%) }\end{array}$ \\
\hline GMA & PAn & 120 & 2 & - & $28.5^{\circ 1}$ & 27.4 \\
\hline GMA & PAn & 120 & 2 & 0.03 & $73.5^{\circ)}$ & 112.2 \\
\hline $\mathbf{E C H}$ & PAn & 120 & 4 & - & 25.1 & 44.5 \\
\hline $\mathrm{ECH}$ & PAn & 120 & 4 & 0.03 & 71.6 & 104.7 \\
\hline SO & PAn & 120 & 2 & - & 33.8 & 55.9 \\
\hline So & PAn & 120 & 2 & 0.03 & 41.3 & 60.4 \\
\hline so & MAn & 120 & 3 & - & $30.6^{(0),(1)}$ & - \\
\hline So & MAn & 120 & 3 & 0.03 & $\left.\left.50.7^{\circ}\right), 8\right)$ & - \\
\hline So & MAn & 80 & 2 & - & $1.5^{\theta)}$ & - \\
\hline So & MAn & 80 & 2 & 0.03 & $\left.22.9^{\circ}\right)$ & 62.4 \\
\hline GPE & SAn & 120 & 5 & - & 3.5 & - \\
\hline GPE & SAn & 120 & 5 & 0.03 & 61.9 & 60.0 \\
\hline
\end{tabular}

a) Neospectra II-COOK, $0.30 \mathrm{~g}$; epoxide =anhydride $=0.01 \mathrm{~mol} ; m$-xylene, $3.0 \mathrm{ml}$. b) GMA, glycidyl methacrylate; ECH, epichlorohydrine; SO, styrene oxide; GPE, glycidyl phenyl ether. c) PAn, phthalic anhydride; MAn, maleic anhydride; SAn, succinic anhydride. a) 18-Crown-6. o) $N$-Phenyl- $\beta$-naphthylamine $(0.02 \mathrm{~g})$ was added. ") Gel containing carbon black was formed.

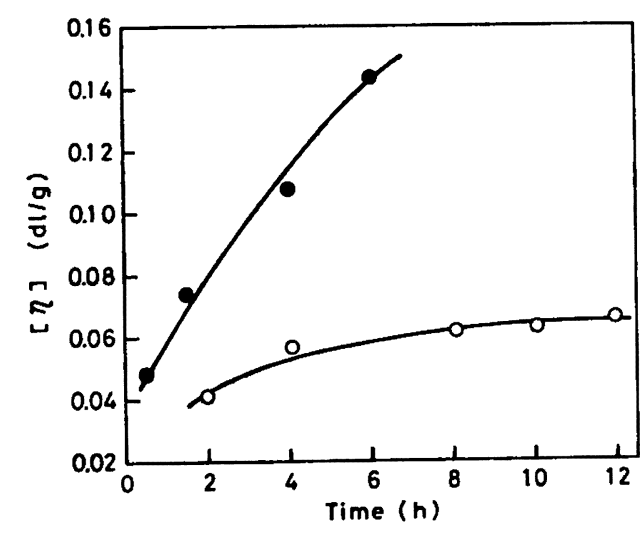

Fig. 4. Effect of 18-crown-6 on the intrinsic viscosity of ungrafted polyester from ECH and PAn (Reaction conditions are given in Fig. 3): (O), in the absence of $\mathrm{CE}$; $(\Theta)$, in the presence of $\mathrm{CE}$; the intrinsic viscosity was measured in chloroform at $30^{\circ} \mathrm{C}$.

くなるが，生長鎖の連鎖移䡃反応す活発になるため， $\mathrm{CB}$ へのポリエステルのグラフト率や非グラフトポリマ

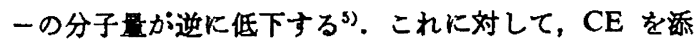
加した系では，共重合速度が著しく大きくなるととも に，容易に高クラフト率のボリェステルクラフト CB を合成できるといら特笄のあることがわかった。

なお,このよらな CB-COOK/CE 開始系で得られる 高クラフト率のポリエステルグラフト CB は, 有機溶 媒中へ極めて安定な分散性を示す.たとえば， ECH と PAn との共重合体をクラフトした Neospectra II（ク

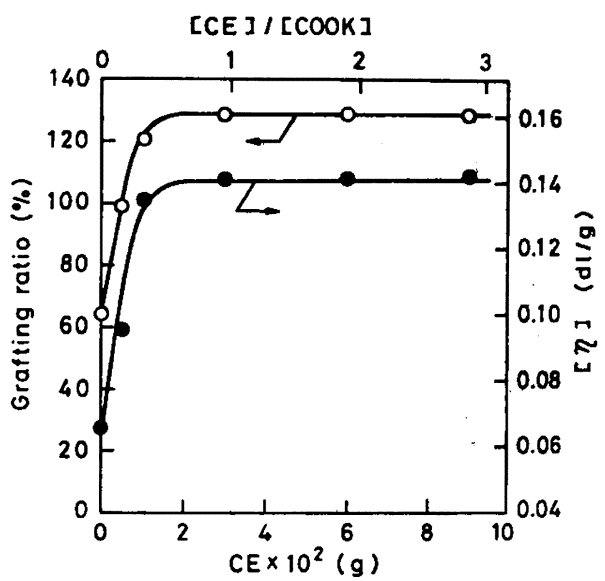

Fig. 5. Effect of the amount of 18-crown-6 on the grafting ratio of polyester and the intrinsic viscosity of ungrafted polyester from $\mathrm{ECH}$ and PAn (Reaction conditions are given in Fig. 1).

ラフト率 $111.7 \%$ ) $0.50 \mathrm{~g}$ をクロロホルム $50 \mathrm{ml}$ に分 散させて, 室温で 6 カ月以上放圈しても沈降するCB 粒 子は, $3 \sim 4 \%$ にすぎなかった.

\section{3 ボリエステルのクラフト售及び非 クラフトホリ マーの梅限粘度と CE 添加量との成係}

Fig. 5 に, ECH と PAn との共重合系に猢石, CE の添加量とグラフト率及び非グラフトポリマーの亚限粘 度（重合率が最高となった時の値をとった）との四低を 示した. 極めて少量のCE を添加したたけですグラフト 率及び非クラフトボリマーの極限粘度は落しく增大し， $\mathrm{CE}$ を $0.02 \mathrm{~g}$ 以上加えてる，グラフト率及ひ非タラフ 
カーポンブラックヘのボリェステルのナニオングラフトロ合に及ぼナクラウンエーテルの添加効果

Table 2. Effect of 18-crown-6 on the copolymerization of ECH with PAn initiated by COOM groups on carbon black a)

\begin{tabular}{lcccc}
\hline Carbon black & $\begin{array}{c}\text { 18-crown-6 } \\
(\mathrm{g})\end{array}$ & $\begin{array}{c}\text { Conversion } \\
(\%)\end{array}$ & $\begin{array}{c}\text { Grafting ratio } \\
(\%)\end{array}$ & $\begin{array}{c}{[\eta]^{\mathrm{b})}} \\
(\mathrm{d} l / \mathrm{g})\end{array}$ \\
\hline Neospectra II-COOLi & - & 6.6 & - & - \\
Neospectra II-COOLi & 0.03 & 9.0 & - & - \\
Neospectra II-COONa & - & 16.2 & 43.0 & 0.041 \\
Neospectra II-COONa & 0.03 & 91.7 & 80.6 & 0.084 \\
Neospectra II-COOK & - & 24.9 & 44.6 & 0.057 \\
Neospectra II-COOK & 0.03 & 92.1 & 106.3 & 0.100 \\
Neospectra II-COOCs & - & 51.4 & 56.0 & 0.057 \\
Neospectra II-COOCs & 0.03 & 90.1 & 100.0 & 0.112 \\
\hline
\end{tabular}

a) Carbon black, $0.30 \mathrm{~g} ; \mathrm{ECH}=\mathrm{PAn}=0.01 \mathrm{~mol}$; $m$-xylene, $3.0 \mathrm{ml}$; temp., $120^{\circ} \mathrm{C}$; time, $2 \mathrm{~h}$. b) Chloroform solution, $30.0^{\circ} \mathrm{C}$.

トポリマーの㢄限粘度は，注とんど增加しない。したが $っ て$, Fig. 5 の結果から, このような共重合系で, 高 グラフト率のポリエステルクラフト CB を得るには, CE を 0.015 0.02 g (Neospectra II 表面の COOK 基 の $50 \sim 70 \mathrm{~mol} \%$ ) 添加すれば十分であることがわかる.

\section{4 各程エボキシトと酸無水物との閒珢共合合に及 偻す CE の奻果}

Table 1 K, COOK 基を刑入した Neospectra II を

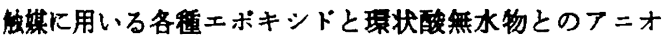
開祡共重合による，ポリエステルのグラフト重合に及 恬すCE の添加奻果をまとめて示した。 エボキシドとし て,クリシシルメタクリラート (GMA), ECH, スチレ ンオキシド (SO), クリシシルフェニルェーテル (GPE) を, 楫状酸無水物として PAn, 無水マレイン酸 (MAn), 無水コハク酸 (SAn) を用いた. なお，モノマーとして， GMA や MAn を用いた系では，生成する不飽和ボリ エステルの䓡重合を防ぐ目的で，重合禁止剂として $N$ -

フェニル-タ-ナフチルアミンを加えた.

いずれの共重合采においてる，CE の添加により重合 速度か增大し，それに伴いCB へのポリエステルのグラ フト帝及び非クララフトポリマーの分子量が増大すること が Table 1 から明らかである.

ところで，モノマーとして GMA や MAnを用いた 共重合系では，高グラフト率のものを得るために重合時 间を延长すると，N-フェニルー $\beta$-ナフチルフミンを添加 してる生成する不飽和ポリェステルが一部反応して，ゲ ルとなる埸合がある。しかしながら，重合系へCEを添 加することКより，低い温度です重合することができる ので,ダルの生成を伴うことなく，高グラフト率の不飽

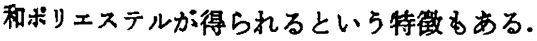

\section{5 各対力チオンに対する CE の効果}

$\mathrm{CE}$ の各稿了ルカリ金属カチオン $\left(\mathrm{M}^{+}\right)$に対する錯体 安定度定数には大きな差があり， $\mathrm{CE}$ Kついては $\mathrm{K}^{+}$と 最良い䈐合性を示す（安定度定数が大きい）ことが知

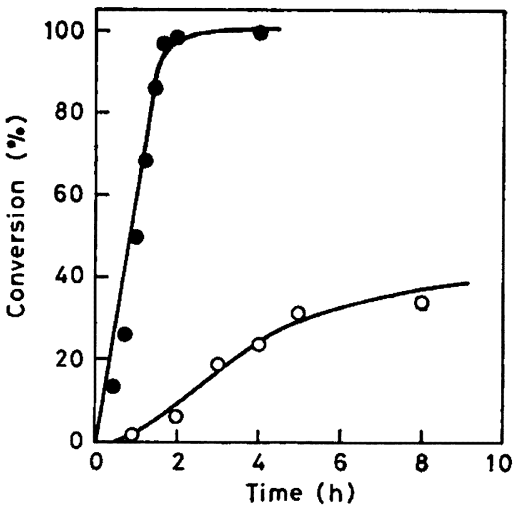

Fig. 6. Effect of 18-crown-6 on the copolymerization of ethylene carbonate (EC) with PAn initiated by COOK groups on carbon black (Neospectra II-COOK, $0.30 \mathrm{~g} ; \mathrm{EC}=\mathrm{PAn}=0.02 \mathrm{~mol} ; 0$ dichlorobenzene, $3.0 \mathrm{ml}$; CE, $0.03 \mathrm{~g}$; temp., 160 $\left.{ }^{\circ} \mathrm{C}\right)$ : $(\mathrm{O})$, in the absence of CE; $(0)$, in the presence of $\mathrm{CE}$.

られている12)。そこで，いろいろな対カチオンを持つカ ルボキシラートアニオンで開始される ECH と PAn と の共重合に及活す CE の効果を調べた結果を Table 2 に示した. いずれの系においても，CE の添加により重 合速度の增大が钼察され, 高グラフト率のポリェステル グラフト CB が得られる.

また，CB-COONa と CB-COOK の系が特に CE の 添加効果加大き，CE の錯体安定化定数か： $\mathrm{K}^{+}, \mathrm{Na}^{+}$ で大きいことと一致する。

3.6 アルキレンカルボナートと 環状酸無水物との開 環共重合に及ぼす CE の効果

CB 表面へ迺入した COOK 基は, ェチレンカルボナ 一ト (EC) やフロビレンカルホホナート (PC) と環状酸無 水物との開環共重合を開始する能力を持ちこのような 


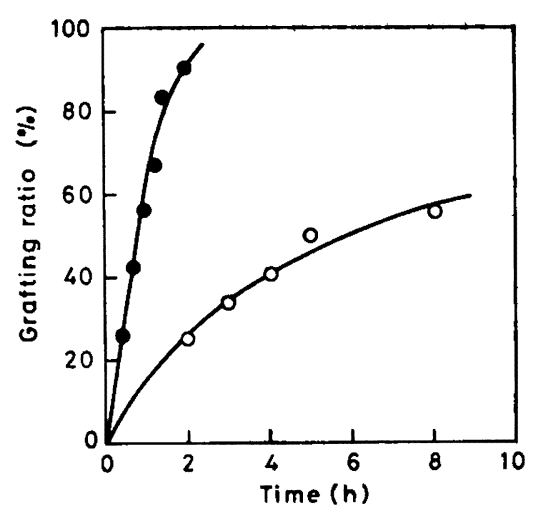

Fig. 7. Effect of 18-crown-6 on the grafting ratio of polyester from EC and PAn (Reaction conditions are given in Fig. 6): (O), in the absence of CE; (๑), in the presence of CE.

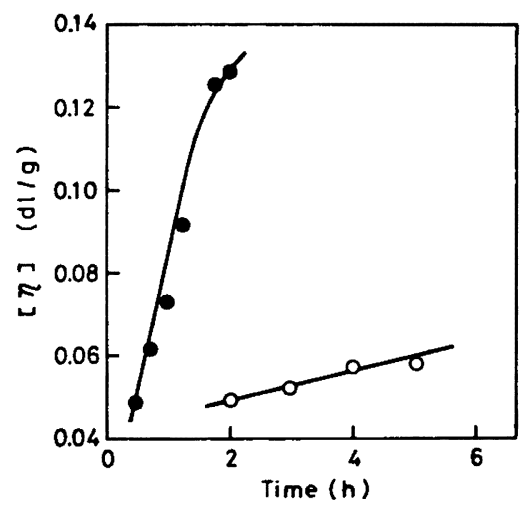

Fig. 8. Effect of 18-crown-6 on the intrinsic viscosity of ungrafted polyester from EC and PAn (Reaction conditions are given in Fig. 6): (O), in the absence of $\mathrm{CE} ;(\bullet)$, in the presence of CE.

系でもCB 表面からポリエステルのアニオン生長が起 こる.しかしながら，重合速度はエポキシドと酸無水物 との共重合反応と比へて遅く，高温 $\left(180 \sim 200^{\circ} \mathrm{C}\right)$ で重 合させないと重合率は大きくならない。

そこで，フルキレンカルボナートと環状酸無水物との 共重合に及ぼす CE の効果について能討した. Fig. 6 は, CB-COOK による EC と PAn との共重合に及ほ す CE の添加効果を示している. 重合温度を $160^{\circ} \mathrm{C} に$ すると, CE の存在しない系では, 重合時間を延长して る重合率は 40\% 以上にならないのに対して, CE の存 在下では短時間の5ちに重合率は $100 \%$ に達し, 初期 重合速度は CE を添加しない系の約 40 倍にも增大す る. また, 同様に PC とPAn との共重合反応につい ても CE の添加効果を調へたところ， $180^{\circ} \mathrm{C}$ の重合温

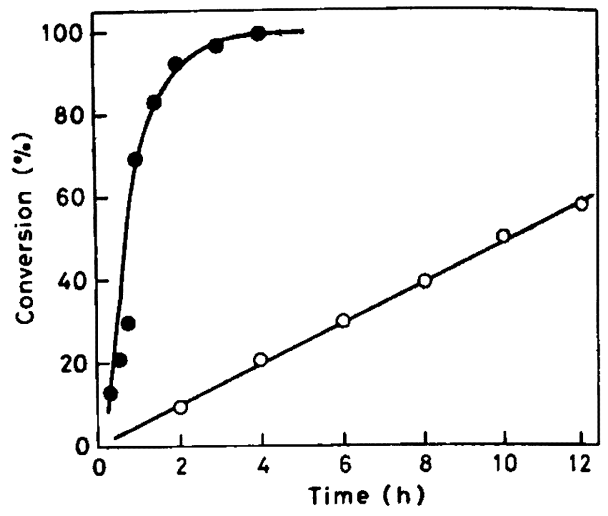

Fig. 9. Effect of 18-crown-6 on the polymerization of $\beta$-propiolactone (PL) initiated by $\mathrm{COOK}$ groups on carbon black (Neospectra II-COOK, $0.30 \mathrm{~g} ; \mathrm{PL}, 0.04 \mathrm{~mol}$; dichloromethane, $3.0 \mathrm{ml}$; $\mathrm{CE}, 0.03 \mathrm{~g}$; temp., $\left.50^{\circ} \mathrm{C}\right):(O)$, in the absence of $\mathrm{CE} ;(\bullet)$, in the presence of CE.

度で，重合速度約 30 倍に加速され，CB-COOK によ るフルキレンカルボナートと環状酸無水物との開祡共重 合においては，CE の添加効果がとくに顕著であること がわかった．また，Fig. 7 及び Fig. 8 に，それでれ， CB へのポリェステル (EC と PAn との共重合体)の グラフト率及び非グラフトポリマーの極限粘度に及注す CE の効果を示した. Fig. 7 及び Fig. 8 から，CEの 添加により CB へのポリェステルのグラフト变及び非 グラフトポリマーの極限粘度が増大することが明らかて ある.

したがって，CB-COOK によるフルキレンカルボナ 一トと喽状酸無水物との共重合系においても, 高グラフ ト率のポリエステルクラフト CB を得るために， CEの 添加が極めて有効であることがわかった.

\subsection{PL のアニオン開理重合に及ばす CE の効果}

すでに著者らは，CB 表面へ学入した COOK 基によ り PL のアニオン開摆重合が開始され，CB 表面からポ リ PL のアニオン生長が起こることを報告しだ.ここ では,このようなアニオン開環ダラフト重合に批いて ๖，CE の添加効果について検討を加えた。

Fig. 9 には，重合速度に及注す CE の添加効果を示 した。先に述へた共重合系と同様, CE の添加により初 期重合速度は 30 倍に增大し, 重合率は 4 時間で $100 \%$ に達する。このような現象は，共重合系と同様，CE の 添加により，カルボキシラートフニオンの見脚けの海度 が增大すること，及び生長速度が增大すること飞起因す るすのと考えられる。

また，Fig. 10 には，この系で得られる CBへのボリ PL のクラフト率に及ぼす CE の効果を示した. CEを 


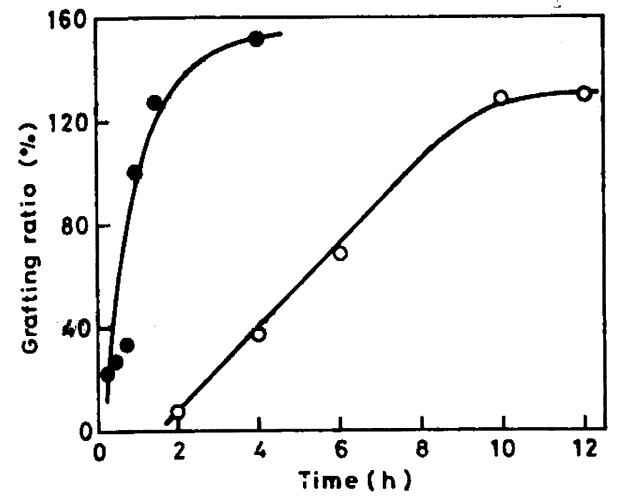

Fig. 10. Effect of 18-crown-6 on the grafting ratio of poly ( $\beta$-propiolactone) onto carbon black (Reaction conditions are given in Fig. 9): (O), in the absence of $\mathrm{CE}$; $(O)$, in the presence of $\mathrm{CE}$.

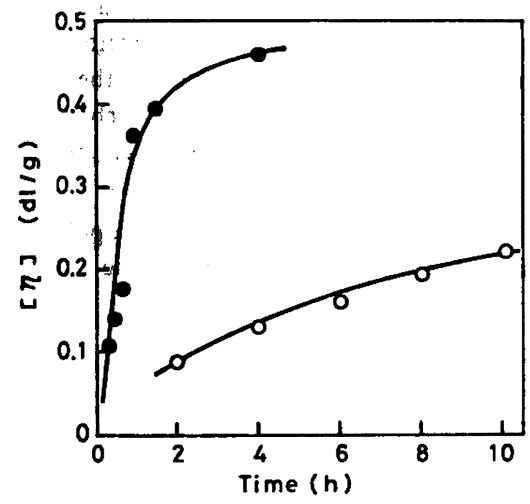

Fig. 11. Effect of 18-crown-6 on the intrinsic viscosity of ungrafted poly-PL (Reaction conditions are given in Fig. 9): (O), in the absence of CE; (O), in the presence of $\mathrm{CE}$.

添加しない系でクララフト率が $120 \%$ を越えるものを得 るためには，長時間（10 時間以上）重合を行ら必要が あったが，CE を添加することにより，短時間( 4 時間) のらちに高クラフト率のすのが得られることがわかる.

更に, このような重合系で生成する非グフラトポリマ 一の柾限粘度を CE の存在下及び存在しない系で比較 した結果を Fig. 11 に示した. Fig. 11 は CE の存在 下では，高分子量のポリ PL が CB 表面へクラフトす ることを示唆している。

なお, Slomkowski らは, 酢酸ナトリウム/CE 系に よるPL の重合はリビング的であることを報告している が7), CB-COOK/CE 系では, 生長頳の連鎖移動反応に よる非クラフトボリマーの生成を伴い, リビンク重合に
Table 3. Effect of 18-crown-6 on the polymerization of VL or CL initiated by COOK groups on carbon black ${ }^{\text {a) }}$

\begin{tabular}{ccccc}
\hline \hline Lactone $^{\mathrm{b})}$ & $\begin{array}{c}\mathrm{CE}^{\mathrm{c})} \\
(\mathrm{g})\end{array}$ & $\begin{array}{c}\text { Temp. } \\
\left({ }^{\circ} \mathrm{C}\right)\end{array}$ & $\begin{array}{c}\text { Time } \\
(\mathrm{h})\end{array}$ & $\begin{array}{c}\text { Conver- } \\
\text { sion } \\
(\%)\end{array}$ \\
\hline VL & - & 50 & 48 & 0 \\
VL & 0.03 & 50 & 48 & 0 \\
VL & 0.03 & 70 & 48 & 0 \\
CL & - & 50 & 48 & 0 \\
CL & 0.03 & 50 & 48 & 0 \\
CL & 0.03 & 70 & 48 & 0 \\
\hline
\end{tabular}

a) Neospectra II-COOK, $0.30 \mathrm{~g}$; lactone, $0.04 \mathrm{~mol}$; dichloromethane, $3.0 \mathrm{ml}$. b) $\mathrm{VL}, \delta$-valerolactone; $\mathrm{CL}, \varepsilon$-caprolactone. ${ }^{\circ)}$ 18-Crown-6.

はならなかった。

ところで, Table 3 に示したよらに, CB-COOK に は六員環の ภ-バレロラクトン (VL) や七員環のを-カフ ロラクトン (CL) の重合を開始する能力がない，そこ で，CE を添加することにより，CB-COOK を活性化 して, VL ゃ CL の重合開始能力を調べたが, CBCOOK にはCE を添加しても，これらのラクトンの 開懪重合を開始する能力がなった (Table 3).

\section{4 括}

CB 表面の COOK 基によるエボキシドあるいはアル キレンカルボナートと環状酸無水物とのフニオン開環共 重合系, 及び PL のアニオン開環重合系へ少量の CE を添加すると，末添加の系と比较して重合速度が 10 40 倍に增大することがわかった. 更に, CE の添加に より, CB へのボリエステルのグラフト率も2 倍以上に 増大し, 高クラフト率のポリエステルグラフト CB を 得るには, 重合系への CE の添加が極めて効果的であ ることを明らかにした。

\section{文萳}

1) N. Tsubokawa, A. Funaki, Y. Hada, and Y. Sone, J. Polym. Sci., Polym. Chem. Ed., 20, 3297 (1982).

2) N. Tsubokawa, A. Yamada, and Y. Sone, Polym. Bull., 10, 63 (1983).

3) N. Tsubokawa, T. Ohyama, A. Yamada, and Y. Sone, J. Polym. Sci., Polym. Chem. Ed., 23, 489 (1985).

4) N. Tsubokawa, A. Funaki, Y. Hada, and Y. Sone, Polym. Bull., 7, 589 (1982).

5) N. Tsubokawa, A. Yamada, and Y. Sone, Polym. J., 16, 333 (1984).

6) 小田良平, 生野利之, 田伏岩夫共編, “クラウ ンエーテルの化学”, 化学同人，京都 (1978), p. 
77.

7) S. Slomkowski and S. Penczek, Macromolecules, 9, 367 (1976).

8) カーボンブラック協会編，“カーボンブラック 便管”図击出版社, 東京 (1971), p. 426.

9) B. Boileau, B. Kaempf, J. M. Lehn, and F. Schué, J. Polym. Sci., Polym. Lett. Ed., 12,
203 (1974).

10) S. Alev, F. Schué, and B. Kaempf, J. Polym. Sci., Polym. Lett. Ed., 13, 397 (1975).

11) A. Deffieux and S. Boileau, Macromolecules, 9, 369 (1976).

12) H. K. Freusdorff, J. Am. Chem. Sbc., 93, 600 (1971).

Effect of Crown Ether on the Anionic Grafting of Polyester from Carbon Black Using COOK Groups on Carbon Black as Catalyst

Norio Tsubokawa*1, Akihiro Yamada*1, and Yasuo Sone*1

*1 Faculty of Engineering, Niigata University (8050, Ikarashi 2-nocho, Niigata, 950-21 Japan)

The effect of crown ether on the ring-opening copolymerization of epoxide or alkylene carbonate with cyclic acid anhydride or the ring-opening polymerization of $\beta$-propiolactone catalyzed by potassium carboxylate (COOK) groups on carbon black was investigated. The copolymerization initiated by COOK groups on carbon black was accelerated by the addition of 18-crown-6 (CE). For instance, the rate of the copolymerization of epichlorohydrine (ECH) with phthalic anhydride (PAn) in the presence of $\mathrm{CE}$ was 10 times as large as the value in its absence. In the absence of $\mathrm{CE}$, conversion of the copolymerization of $\mathrm{ECH}$ with PAn was smaller than $40 \%$ and the maximum grafting ratio of polyester onto carbon black was $63 \%$. In the presence of $\mathrm{CE}$, however, the copolymerization proceeded quantitatively and the grafting ratio increased up to $128.5 \%$. In addition, ungrafted polyester with a higher molecular weight was formed in the presence of $\mathrm{CE}$. The addition of $\mathrm{CE}$ to the system of the ring-opening copolymerization of alkylene carbonate with cyclic acid anhydride or the ring-opening polymerization of $\beta$-propiolactone initiated by COOK groups was very effective for the preparation of polyester-grafted carbon black with a higher grafting ratio.

KEY WORDS Carbon Black / Grafting from Carbon Black / Crown Ether / Ring-Opening Copolymerization / Polyester-Grafted Carbon Black / $\beta$-Propiolactone / Epoxide / Cyclic Acid Anhydride / Alkylene Carbonate /

(Received March 30, 1985: Accepted May 9, 1985)

[Kobunshi Ronbunshu, 42 (8), 509-516 (1985)] 